\title{
Pengaruh Model Pembelajaran Discovery Learning Terhadap Hasil Belajar IPA
}

\author{
Pt. Gede Oki Artawan ${ }^{1 *}$, Ny. Kusmariyatni², Dw. Ny. Sudana ${ }^{3}$ iD \\ 1,2,3 Program Studi Pendidikan Guru Sekolah Dasar, Universitas Pendidikan Gansha, Bali, Indonesia \\ *Corresponding author: okiartawan95@gmail.com
}

\begin{abstract}
Abstrak
Penelitian ini bertujuan untuk mengetahui pengaruh yang signifikan Model Pembelajaran Discovery Learning Terhadap Hasil Belajar IPA Siswa Kelas V SD. Penelitian eksperimen ini menggunakan rancangan non-equivalent post test only control group design. Populasi penelitian ini adalah seluruh siswa kelas V SD. Sampel diambil dengan teknik random sampling. Data yang telah dikumpulkan dianalisis dengan statistik deskriptif dan uji-t independent. Hasil penelitian menujukkan bahwa hasil belajar IPA kelompok eksperimen lebih besar dari kelompok kontrol yaitu 18,04>15,23. Hasil perhitungan uji-t independent diperoleh $t_{\text {hitung }}=2,533$ dan $t_{\text {tabel }}=2,0$ ( $\left.t_{\text {hitung }}>\mathrm{t}_{\text {tabel }}\right)$ pada taraf signifikansi 5\%. Dengan demikian model pembelajaran Discovery Learning berpengaruh terhadap hasil belajar IPA.
\end{abstract}

Kata kunci: Discovery Learning, Hasil Belajar IPA

\section{Abstract}

This study aims to determine the significant effect of the Discovery Learning Learning Model on Science Learning Outcomes of Class V Students in Cluster 3 Seririt District 2019/2020 Academic Year. This experimental research uses a non-equivalent post test only control group design. The population of this research is all fifth grade elementary school students in Cluster 3 Seririt District 2019/2020 Academic Year. Samples were taken by random sampling technique. The data collected was analyzed with descriptive statistics and independent t-test. The results showed that the science learning outcomes of the experimental group were greater than the control group of 18.04> 15.23. The results of independent $t$-test calculations obtained tcount $=2.533$ and ttable $=2.0$ (tcount $>$ ttable) at a significance level of 5\%. Thus the learning model Discovery Learning affects the learning outcomes of Natural Sciences

Keywords: Discovery Learning, Learning Outcome

\section{Introduction}

Berdasarkan Pancasila dan Undang-Undang Dasar Negara Republik Indonesia Tahun 1945 pendidikan nasional berfungsi untuk mengembangkan kemampuan dan membentuk watak serta peradaban bangsa yang bermartabat dalam rangka mencerdaskan kehidupan bangsa.Pengembangan kurikulum yang telah disesuaikan dengan kebutuhan dan potensi daerah yang ada akan mendukung tercapainya pendidikan yang sesuai dan berkualitas. Hal tersebut bertujuan untuk mempermudah proses kegiatan belajar mengajar, serta berbagai usaha lain yang tentunya dapat meningkatkan kualitas pendidikan. Pendidikan Indonesia berada di peringkat ke-64 untuk pendidikan di seluruh dunia dari 120 negara (Putrayasa et al., 2014). Rendahnya kualitas pendidikan pada jenjang formal maupun informal terjadi pada lima mata pelajaran yang diutamakan khususnya pada jenjang SD. Rendahnya kualitas pendidikan pada kelima mata pelajaran tersebut harus segera dicarikan jalan keluarnya. Terutama rendahnya kualitas pendidikan pada mata pelajaran Ilmu Pengetahuan Alam (IPA).

Mata pelajaran IPA merupakan mata pelajaran yang selama ini dianggap sulit oleh sebagian besar peserta didik, mulai dari jenjang sekolah dasar sampai sekolah menengah

$\begin{array}{lll}\text { History: } & & \text { Publisher: Undiksha Press } \\ \text { Received } & : \text { 7 September } 2020 & \text { Licensed: This work is licensed under } \\ \text { Revised } & : 11 \text { September } 2020 & \text { a Creative Commons Attribution 3.0 License } \\ \text { Accepted } & : 6 \text { November } 2020 & \end{array}$


(Hermiyanty, Wandira Ayu Bertin, 2017). Mata pelajaran IPA merupakan bagian dari kehidupan manusia sejak manusia mengenal diri dan alam sekitarnya. Manusia dan lingkungan merupakan sumber, obyek dan subyek sains. Secara sederhana dapat dikatakan bahwa IPA merupakan pengalaman manusia yang masing-masing individu itu dirasakan atau dimaknai berbeda atau sama (Ali, 2018).

Berdasarkan hasil wawancara pada tanggal 20 November 2019 terungkap beberapa permasalahan yang teridentifikasi. Dapat dikatakan bahwa (1) rendahnya hasil belajar IPA siswa kelas V SD di Gugus 3 Kecamatan Seririt, (2) kurangnya komunikasi antara siswa dan guru, (3) rendahnya pengawasan saat jam pelajaran mulai. Sedangkan dilihat dari hasil observasi yang menjadi permasalahan di Sekolah yaitu lemahnya pelaksanaan proses pembelajaran IPA yang diterapkan guru. Dapat dikatakan bahwa (1) guru hanya membuat media pelajaran dengan contoh gambar maka siswa tersebut mengasai materi IPA, (2) pada proses pembelajaran berlangsung belum pernah menerapka observasi di lingkungan sekolah yang dimana guru-guru lain tidak pernah menyaksikan proses pembelajaran di lingkungan sekolah, (3) guru tidak pernah mengadakan diskusi setelah berlangsungnya proses pembelajaran berlangsung. Hal ini mengakibatkan proses pembelajaran jarang dikritik oleh pendidik lainnya untuk dapat diberikan masukan-masukan tentang pelajaran IPA. Pembelajaran IPA masih didominasi metode ceramah dan pemberian tugas. Proses pembelajaran yang dilakukan selama ini kurang mampu mengembangkan kemampuan berpikir siswa. Selain itu, dalam proses pembelajaran kebanyakan guru hanya terpaku pada buku teks sebagai satu-satunya sumber belajar mengajar.

Menurut Kristin (2016) proses pembelajaran dapat berlangsung karena adanya siswa, guru, kurikulum, satu dengan yang lain saling terkait atau saling berhubungan. Siswa dapat belajar dengan baik jika sarana dan prasarana untuk belajar memadai, model pembelajaran guru menarik, siswa ikut aktif dalam proses pembelajaran sehingga siswa tidak merasa jenuh atau bosan ketika mengikuti pembelajaran di kelas. Selain itu, hasil belajar siswa juga sangat mempengaruhi permasalahan pada proses pembelajaran IPA di SD. Siswa yang memiliki hasil belajar tinggi selalu berusaha mengikuti proses pembelajaran dengan sebaik-baiknya untuk memperoleh hasil belajar yang optimal. Salah satu model yang bisa digunkana dalam proses pembelajaran adalah model Discovery Learning. Putrayasa et al (2014) menjelaskan bahwa Discovery Learning adalah suatu tipe pembelajaran dimana siswa membangun pengetahuan mereka sendiri dengan mengadakan suatu percobaan dan menemukan sebuah prinsip dari hasil percobaan tersebut. Discovery Learning merupakan komponen dari praktek pendidikan yang meliputi metode mengajar yang memajukan cara belajar aktif, berorientasi pada proses, mengarahkan sendiri dan reflektif (Irwan et al., 2020). Patandung (2017) model pembelajaran discovery learning merupakan komponen dari suatu bagian praktek pengajaran, yaitu suatu jenis mengajar yang meliputi metode metode yang dirancang untuk meningkatkan rentangan keaktifan siswa yang lebih besar, berorientasi kepada proses, mengarahkan pada diri sendiri, mencari sendiri dan refleksi yang sering muncul sebagai kegiatan belajar. Penerapan model pembelajaran Discovery Learning di SD terutama pada mata pelajaran IPA menjadi sangat tepat dikarenakan model pembelajaran ini memiliki beberapa kelebihan yaitu: 1) menambah pengalaman siswa dalam belajar, 2) memberikan kesempatan kepada siswa untuk lebih dekat lagi dengan sumber pengetahuan selain buku, 3) menggali kreatifitas siswa, 4) mampu meningkatkan rasa percaya diri pada siswa, dan 5) meningkatkan kerja sama antar siswa (Mutmainna \& Jafar, 2015).

Belajar dengan model Discovery Learning biasanya dimulai dengan menghadapkan siswa pada satu masalah. Selanjutnya siswa berusaha untuk membandingkan kenyataan di lingkungannya dengan yang tersedia pada struktur mental yang telah dimilikinya. Melalui pengalaman yang telah dimilikinya, siswa mencoba untuk menyesuaikan atau mengorganisasikan kembali struktur-struktur agar mencapai keadaan seimbang. Untuk itu 
siswa harus mencoba, mengadakan analisis, menemukan informasi baru, menyingkirkan informasi yang tidak perlu, kemudian menjadikannya sebagai pengetahuan barunya jadi model discovery learning juga dapat melatih sikap ilmiah siswa (Widiadnyana et al., 2014). Hal tersebut lebih didukung lagi berdasarkan beberapa hasil penelitian yang pernah dilakukan dengan menerapkan model pembelajaran Discovery Learning. Beberapa hasil penelitian menjelaskan bahwa hasil belajar dalam pembelajaran IPA setelah diterapkan model pembelajaran Discovery Learning mengalami peningkatan yang signifikan.

Pembelajaran dengan menggunakan model pembelajaran Discovery Learning didukung oleh beberapa penelitian yaitu menurut Kanna et al., (2018), diperoleh bahwa hasil penelitian menunjukkan bahwa terdapat peningkatan dalam kreativitas dan hasil belajar IPA. Peningkatan kreativitas belajar siswa terjadi secara bertahap, pada pra siklus siswa masuk dalam kategori tidak kreatif dengan presentase $32 \%$, pada siklus I mengalami peningkatan menjadi kategori cukup kreatif dengan presentase sebesar $80 \%$, pada siklus II juga mengalami peningkatan menjadi kategori kreatif dengan presentase $96 \%$. Begitu pula dengan peningkatan hasil belajar IPA mengalami peningkatan secara bertahap, pada pra siklus dengan presentase ketuntasan $20 \%$ dengan rata-rata 58,4, pada siklus I meningkat dengan presentase ketuntasan $56 \%$, pada siklus II juga mengalami peningkatan dengan presentase $92 \%$ dengan rata-rata 85,8 . Jadi, dapat disimpulkan bahwa pada model pembelajaran Discovery Learning dapat meningkatkan kreativitas dan hasil belajar IPA. Penelitian lain dengan menggunakan Discovery Learning. Menurut Pamungkas et al., (2019) diperoleh hasil bahwa hasil belajar IPA setelah diterapkan model pembelajaran Discovery Learning dapat berhasil meningkatkan hasil belajar siswa pada muatan pelajaran IPA dalam Tema 6 subtema 3 kelas 5 di SD Negeri Tegalrejo 02 Salatiga. Dapat dilihat apabila pada pra siklus hanya (52\%) 13 siswa yang masuk kategori tuntas, setelah melakukan tahap siklus I mengalami kenaikan menjadi (63\%) 17 siswa yang masuk kategori tuntas dan hasil belajar mengalami peningkatan kembali pada siklus II menjadi (89\%) 24 siswa yang tuntas.

Tujuan dari penelitian ini untuk mengetahui pengaruh Model Pembelajaran Discovery Learning Terhadap Hasil Belajar IPA siswa kelas V SD di Gugus 3 Kecamatan Seririt Tahun Pelajaran 2019/2020.

\section{Materials and Methods}

Penelitian yang dilaksanakan ini termasuk jenis penelitian eksperimen. Dalam melakukan eksperimen peneliti memanipulasikan suatu stimulan, treatment atau kondisi-kondisi eksperimental, kemudian menobservasi pengaruh yang diakibatkan oleh adanya perlakuan atau manipulasi tersebut (Ikm \& Ugm, 2011). Lebih tepatnya lagi penelitian yang dilakukan ini berupa eksperimen semu (quasi experiment) karena tidak semua variabel (gejala yang muncul) dan kondisi eksperimen dapat diatur dan dikontrol secara ketat.

Populasi dalam penelitian ini adalah seluruh siswa kelas V di SD Gugus 3, Kecamatan Seririt Tahun Pelajaran 2019/2020. Populasi yang ada dipilih menggunakan teknik pengundian (random sampling) untuk menentukan sampel yang digunakan dalam penelitian ini. Teknik pengundian ini dilakukan karena tidak memungkinkan diadakannya pengambilan subjek penelitian secara acak dari populasi yang ada, karena subjek (siswa) secara alami telah terbentuk dalam satu kelompok (satu kelas). Teknik random sampling dilakukan dengan sistem undian (Finch \& Gordon, 2013).

Berdasarkan hasil undian didapatkan 2 kelas sebagai sampel yaitu kelas V SD N 1 dan kelas V SD N 3 Seririt. Tahap 2 menentukan kelas eksperimen dan kelas kontrol, dari 2 kelas yang diundi ditemukan kelas V SD N 1 Seririt sebagai kelas eksperimen dan kelas V SD N 3 Seririt sebagai kelas kontrol.

Dalam penelitian ini, perlakuan diberikan pada kelas eksperimen dengan menggunakan model pembelajaran Discovery Learning. Model pembelajaran Discovery Learning 
merupakan model pembelajaran yang mengarahkan siswa berinteraksi dengan lingkungannya dengan jalan mengekspor dan memanipulasi obyek, bergulat dengan sejumlah pertanyaan dan kontroversi atau melakukan percobaan (Ratnasari \& Erman, 2017). Ide dasar teori ini yaitu siswa menjadi mudah dalam mengingat suatu konsep jika konsep tersebut mereka dapatkan sendiri melalui proses belajar penemuan. Sedangkan pada kelas kontrol tidak diberikan perlakuan secara khusus artinya belajar tidak dengan model pembelajaran discovery learning, hanya saja disesuaikan dengan model pembelajaran yang biasa guru gunakan di sekolah. Setelah perlakuan di kelas kontrol maupun di kelas eksperimen akan diberikan post-test untuk mengetahui hasil belajar masing-masing kelompok, baik kelas eksperimen ataupun kelas kontrol.

Instrumen pengumpulan data yang digunakan dalam penelitian ini adalah berupa tes objektif. Soal objektif yang digunakan terdiri dari 30 butir soal. Untuk menentukan butir soal instrumen tersebut layak untuk diberikan terhadap kelompok sampel terlebih dahulu dilakukan uji coba. Uji coba tes hasil belajar IPA meliputi: validitas butir tes, reliabilitastes tes, daya beda tes, dan tingkat kesukaran tes. Analisis data dalam penelitian ini dilakukan dalam tiga tahap. Pada tahap pertama dilakukan analisis deskriptif, tahap kedua digunakan analisis uji coba prasyarat untuk pembuktian persyaratan analisis statistik. Sedangkan pada tahap ketiga dilakukan analisis untuk pembuktian hipotesis.

Pengujian terhadap hipotesis penelitian yang telah dirumuskan dilakukan melalui metode statistika, hipotesis pertama dilakukan dengan menggunakan analisis Uji Independent Sample t-test. Sebelum dilakukan uji hipotesis terlebih dahulu dilakukan uji prasyarat analisis yang meliputi uji normalitas sebaran data, uji homogenitas varians.

\section{Results and Discussion}

\section{Hasil penelitian}

Pengukuran dilakukan setelah kelompok eksperimen diberikan perlakuan berupa model pembelajaran discovery learning dan kelompok kontrol tidak diberikan perlakuan model pembelajaran discovery learning, dengan jumlah pertemuan sebanyak tujuh kali pertemuan. Hasil analisis statistik deskriptif data penelitian ini disajikan pada Tabel 1.

Tabel 1. Rekapitulasi Deskripsi Hasil Penelitian

\begin{tabular}{lcc}
\hline & \multicolumn{2}{c}{ Hasil Belajar } \\
Statistik Deskriptif & Kelompok Eksperimen & Kelompok Kontrol \\
\hline Mean & 18,04 & 15,23 \\
Median & 18,5 & 14,98 \\
Modus & 20,2 & 14,5 \\
Varians & 23,56 & 18,63 \\
Standar Deviasi & 4,85 & 4,32 \\
\hline
\end{tabular}

Berdasarkan Tabel 1, menunjukkan bahwa hasil belajar IPA siswa kelompok eksperimen lebih tinggi dibandingkan dengan siswa kelompok kontrol. Tinjauan ini didasarkan pada rata-rata skor dan kecenderungan skor hasil belajar IPA yang diperoleh kedua kelompok. Rata-rata skor hasil belajar IPA siswa kelompok eksperimen adalah 18,04 (kategori tinggi). Begitu pula yang tampak pada kurva poligon, yang mana sebaran data kelompok ini merupakan juling negatif. Artinya, sebagian besar skor siswa cenderung tinggi. Pada kelompok kontrol, rata-rata skor hasil belajar IPA siswa adalah 15,23 (kategori sedang). Kurva sebaran data merupakan juling positif, yang artinya sebagian besar skor siswa cenderung rendah. Dengan demikian, hasil belajar kelompok eksperimen lebih tinggi dibandingkan dengan hasil belajar kelompok kontrol. Berdasarkan uji prasyarat analisis data, diperoleh bahwa data hasil belajar 
IPA siswa kelompok eksperimen dan kontrol adalah normal dan homogen. Pengujian hipotesis dilakukan menggunakan independent sample t-test. Berdasarkan hasil uji hipotesis diperoleh bahwa $t_{\text {hitung }}$ sebesar 2,533, sedangkan, $t_{\text {tabel }}$ dengan $\mathrm{dk}=49$ pada taraf signifikansi $5 \%$ adalah 2,0. Hal ini berarti, $t_{\text {hitung }}$ lebih besar dari $t_{\text {tabel }}\left(t_{\text {hitung }}>t_{\text {tabel }}\right)$ sehingga $\mathrm{H}_{0}$ ditolak dan $\mathrm{H}_{1}$ diterima. Dengan demikian, dapat diinterpretasikan bahwa terdapat perbedaan yang signifikan pada hasil belajar IPA antara siswa yang belajar dengan model pembelajaran discovery learning dan siswa yang tidak belajar dengan model pembelajaran Discovery Learning pada siswa kelas V SD di Gugus 3 Kecamatan Seririt Tahun Pelajaran 2019/2020. Besarnya pengaruh model pembelajaran discovery learning dan yang tidak belajar dengan model pembelajaran discovery learning terhadap hasil belajar dapat dibuktikan dari hasil analisis deskriptif. Hasil analisis deskriptif menunjukkan bahwa rata-rata skor hasil belajar IPA kelompok eksperimen, yaitu 18,04 lebih tinggi daripada kelompok kontrol, yaitu 15,23.

\section{Pembahasan}

Temuan penelitian yang menunjukkan bahwa model pembelajaran discovery learning berpengaruh terhadap hasil belajar IPA siswa dengan kecenderungan sebagian besar skor siswa tinggi disebabkan oleh beberapa faktor. Faktor pertama, model discovery learning dapat melatih siswa untuk menemukan sendiri informasi dan pengetahuannya berdasarkan hasil yang diperolehnya melalui pengamatannya (Irwan et al., 2020). Belajar dengan model Discovery Learning biasanya dimulai dengan menghadapkan siswa pada satu masalah. Selanjutnya siswa berusaha untuk membandingkan kenyataan di lingkungannya dengan yang tersedia pada struktur mental yang telah dimilikinya. Melalui pengalaman yang telah dimilikinya, siswa mencoba untuk menyesuaikan atau mengorganisasikan kembali struktur-struktur agar mencapai keadaan seimbang. Untuk itu siswa harus mencoba, mengadakan analisis, menemukan informasi baru, menyingkirkan informasi yang tidak perlu, kemudian menjadikannya sebagai pengetahuan barunya jadi model discovery learning juga dapat melatih sikap ilmiah siswa (Widiadnyana et al., 2014).

Faktor kedua, dengan diterapkannya model pembelajaran discovery learning mampu melatih siswa lebih mandiri, tanggungjawab serta mampu memecahkan masalah sendiri tanpa menunggu arahan dari guru. Putrayasa et al (2014) menjelaskan bahwa Discovery Learning adalah suatu tipe pembelajaran dimana siswa membangun pengetahuan mereka sendiri dengan mengadakan suatu percobaan dan menemukan sebuah prinsip dari hasil percobaan tersebut. Discovery Learning merupakan komponen dari praktek pendidikan yang meliputi metode mengajar yang memajukan cara belajar aktif, berorientasi pada proses, mengarahkan sendiri dan reflektif (Irwan et al., 2020). Patandung (2017) model pembelajaran discovery learning merupakan komponen dari suatu bagian praktek pengajaran, yaitu suatu jenis mengajar yang meliputi metode metode yang dirancang untuk meningkatkan rentangan keaktifan siswa yang lebih besar, berorientasi kepada proses, mengarahkan pada diri sendiri, mencari sendiri dan refleksi yang sering muncul sebagai kegiatan belajar. Penerapan model pembelajaran Discovery Learning di SD terutama pada mata pelajaran IPA menjadi sangat tepat dikarenakan model pembelajaran ini memiliki beberapa kelebihan yaitu: 1) menambah pengalaman siswa dalam belajar, 2) memberikan kesempatan kepada siswa untuk lebih dekat lagi dengan sumber pengetahuan selain buku, 3) menggali kreatifitas siswa, 4) mampu meningkatkan rasa percaya diri pada siswa, dan 5) meningkatkan kerja sama antar siswa (Mutmainna \& Jafar, 2015).

Pembelajaran dengan menggunakan model pembelajaran Discovery Learning didukung oleh beberapa penelitian yaitu menurut Kanna et al., (2018), diperoleh bahwa hasil penelitian menunjukkan bahwa terdapat peningkatan dalam kreativitas dan hasil belajar IPA. Peningkatan kreativitas belajar siswa terjadi secara bertahap, pada pra siklus siswa masuk dalam kategori tidak kreatif dengan presentase 32\%, pada siklus I mengalami peningkatan menjadi kategori cukup kreatif dengan presentase sebesar $80 \%$, pada siklus II juga mengalami 
peningkatan menjadi kategori kreatif dengan presentase $96 \%$. Begitu pula dengan peningkatan hasil belajar IPA mengalami peningkatan secara bertahap, pada pra siklus dengan presentase ketuntasan $20 \%$ dengan rata-rata 58,4, pada siklus I meningkat dengan presentase ketuntasan $56 \%$, pada siklus II juga mengalami peningkatan dengan presentase $92 \%$ dengan rata-rata 85,8 . Jadi, dapat disimpulkan bahwa pada model pembelajaran Discovery Learning dapat meningkatkan kreativitas dan hasil belajar IPA. Penelitian lain dengan menggunakan Discovery Learning. Menurut Pamungkas et al., (2019) diperoleh hasil bahwa hasil belajar IPA setelah diterapkan model pembelajaran Discovery Learning dapat berhasil meningkatkan hasil belajar siswa pada muatan pelajaran IPA dalam Tema 6 subtema 3 kelas 5 di SD Negeri Tegalrejo 02 Salatiga. Dapat dilihat apabila pada pra siklus hanya (52\%) 13 siswa yang masuk kategori tuntas, setelah melakukan tahap siklus I mengalami kenaikan menjadi (63\%) 17 siswa yang masuk kategori tuntas dan hasil belajar mengalami peningkatan kembali pada siklus II menjadi (89\%) 24 siswa yang tuntas.

\section{Conclusion}

Berdasarkan hasil uji statistika yang telah dilakukan diperoleh hasil bahwa terdapat perbedaan yang signifikan pada hasil belajar IPA antara siswa yang belajar dengan model pembelajaran discovery learning dan siswa yang tidak belajar dengan model pembelajaran discovery learning. Adanya perbedaan yang signifikan menunjukkan bahwa model pembelajaran discovery learning berpengaruh terhadap hasil belajar IPA siswa.

\section{References}

Ali, L. U. (2018). Pengelolaan Pembelajaran IPA Ditinjau Dari Hakikat Sains Pada SMP Di Kabupaten Lombok Timur. Prisma Sains : Jurnal Pengkajian Ilmu Dan Pembelajaran Matematika Dan IPA IKIP Mataram, 6(2), 103. https://doi.org/10.33394/j-ps.v6i2.1020

Finch, S., \& Gordon, I. (2013). Probability and statistics: Random sampling. 6, 10, 12.

Hermiyanty, Wandira Ayu Bertin, D. S. (2017). Pendekatan Konsep Dan Pendekatan Lingkungan. In Journal of Chemical Information and Modeling (Vol. 8, Issue 9).

Ikm, P., \& Ugm, F. K. (2011). Penelitian Eksperimen Penelitian Eksperimen. 1-38.

Irwan, F., Hadi, K., \& Rahman, A. A. (2020). Pengaruh Pembelajaran Discovery Learning Berbasis Media Torso Pada Materi Sistem Pernafasan Terhadap Hasil Belajar Siswa Kelas Xi Sma Negeri 1 Pante Ceureumen Kec Pante Ceureumen. VII(1), 75-78.

Kanna, R., Kristin, F., \& Anugraheni, I. (2018). Penerapan Model Pembelajaran Discovery Learning Untuk Meningkatkan Kreativitas Dan Hasil Belajar Pada Mata Pelajaran Ipa Kelas 5 SD. Kalam Cendekia, 6(4.1), 1-8. http://jurnal.fkip.uns.ac.id/index.php/pgsdkebumen/article/view/11960/8532

Kristin, F. (2016). Analisis Model Pembelajaran Discovery Learning dalam Meningkatkan Hasil Belajar Siswa SD. Jurnal Pendidikan Dasar Perkhasa, 2(1).

Mutmainna, M., \& Jafar, A. F. (2015). Komparasi Hasil Belajar Fisika melalui Metode Discovery Learning dan Assignment And Recitation. Jurnal Pendidikan Fisika, 3(1), 4651.

Pamungkas, G. H., Harjono, N., \& Airlanda, G. S. (2019). Peningkatan Proses Dan Hasil Belajar Ipa Kelas 5 Tema 6 Subtema 3 Dengan Model Pembelajaran Discovery Learning. Jurnal Basicedu, 3(1), 43-46. https://doi.org/10.31004/basicedu.v3i1.64

Patandung, Y. (2017). Pengaruh model discovery learning terhadap peningkatan motivasi belajar IPA Siswa. Journal of Educational Science and Technology (EST), 3(1), 9. 
Putra, I. D. G. W., Agung, A. A. G., \& Parmiti, D. P. (2017). Pengaruh Model Pembelajaran Discovery Learning Berbasis Lingkungan Terhadap Hasil Belajar Ipa Pada Siswa Kelas V Semester Genap Tahun Pelajaran. Mimbar PGSD Undiksha, 5(2), 1-10.

Putrayasa, I. M., Syahruddin, H., \& Mergunayasa, I. G. (2014). Pengaruh Model Pembelajaran Discovery Learning Dan Minat Belajar Terhadap Hasil Belajar Ipa Siswa. Jurnal Mimbar PGSD Universitas Pendidikan Ganesha, 2(1), 1-11. http://ejournal.undiksha.ac.id/index.php/JJPGSD/article/view/3087

Ratnasari, R. Y., \& Erman. (2017). Penerapan Model Discovery Learning Dalam Pembelajaran IPA Materi Zat Aditif Untuk Melatih Keterampilan Proses Sains Siswa SMP. E-Jurnal Pensa, 5(3), 325-329.

Widiadnyana, I., Sadia, M., \& Suastra, M. (2014). Pengaruh Model Discovery Learning Terhadap Pemahaman Konsep Ipa Dan Sikap Ilmiah Siswa Smp. Jurnal Pendidikan Dan Pembelajaran IPA Indonesia, 4(2). 